\title{
Effects of Feeding Dry Glycerin to Early Postpartum Holstein Dairy Cows on Lactational Performance and Metabolic Profiles
}

\author{
Y.-H. Chung, ${ }^{*}$ D. E. Rico, ${ }^{\star}$ C. M. Martinez, ${ }^{\star}$ T. W. Cassidy, ${ }^{*}$ V. Noirot,† A. Ames,‡ and G. A. Varga ${ }^{* 1}$ \\ *Department of Dairy and Animal Science, The Pennsylvania State University, University Park 16802 \\ †Phodé S.A., Albi Terssac, France \\ $\ddagger$ NutriLinx, LLC., Montpelier, VT 05602
}

\section{ABSTRACT}

Effects of feeding a dry glycerin product (minimal $65 \%$ of food grade glycerol, dry powder) to 39 multiparous Holstein dairy cows (19 control and 20 glycerinsupplemented; lactation number $=2.2 \pm 1.3 \mathrm{SD}$ ) on feed intake, milk yield and composition, and blood metabolic profiles were investigated. Dry glycerin was fed at 250 $\mathrm{g} / \mathrm{d}$ as a top dressing (corresponding to $162.5 \mathrm{~g}$ of glyc$\mathrm{erol} / \mathrm{d}$ ) to the common lactating total mixed ration from parturition to $21 \mathrm{~d}$ postpartum. Individual milk was sampled from 2 consecutive milkings weekly and analyzed for components. Blood was sampled from the coccygeal vein at $4,7,14$, and $21( \pm 0.92$, pooled SD) $d$ in milk and analyzed for urea nitrogen, glucose, insulin, nonesterified fatty acids, and $\beta$-hydroxybutyrate. Urine was tested for the acetoacetate level weekly by using Ketostix. Average feed intake, milk yield and components, blood metabolites, and serum insulin concentrations were not affected by dry glycerin supplementation. Glycerin-supplemented cows experienced a more positive energy status (higher concentrations of plasma glucose, lower concentrations of plasma $\beta$-hydroxybutyrate, and lower concentrations of urine ketones), which was observed during the second week of lactation, suggesting that energy availability may have been improved. This glucogenic effect of dry glycerin did not result in an increase in feed intake or milk yield during the first $3 \mathrm{wk}$ of lactation, likely because of the relatively less negative energy status of cows transitioning into lactation. The tendency toward higher milk yield for glycerin-supplemented cows during wk 6 of lactation $(52$ vs. $46 \mathrm{~kg} / \mathrm{d}$ ) after the supplementation period (dry glycerin was terminated at wk 3 of lactation) suggested a potential benefit of dry glycerin on subsequent milk production, perhaps through changes in metabolism, which requires further investigation.

Received June 7, 2007

Accepted August 28, 2007

${ }^{1}$ Corresponding author: gvarga@psu.edu
Key words: glycerol, early postpartum dairy cow, milk yield, blood metabolic profile

\section{INTRODUCTION}

Glycerol is an important structural component of triglycerides and phospholipids. The glucogenic property of glycerol is well established (Cori and Shine, 1935). When the body uses body fat reserves as a source of energy, glycerol and fatty acids are released into the bloodstream. The glycerol component can be converted to glucose by the liver (Krebs et al., 1966) and kidneys (Krebs and Lund, 1966) and provides energy for cellular metabolism. As early as the 1950 s, glycerol was used to treat ketosis in dairy cows via drenching orally, feeding with concentrates, or both, with a relatively large dose (Johnson, 1951, 1954). At that time, however, the cost of glycerol made it less economically feasible as a treatment for ketosis compared with propylene glycol. More recently, surplus production of glycerin (or glycerol) from biodiesel fuel production has made various forms of glycerin an attractive glucogenic substrate for feeding livestock.

Surplus glycerin from biodiesel fuel production will likely flood glycerin supplies for the traditional uses, although there are many applications for glycerin, such as using it as an energy source in livestock diets. From very limited research, glycerin has been fed as a feed ingredient to replace energy sources such as corn for up to $10 \%$ of the total ration DM for broiler chickens (Simon et al., 1996) without negatively affecting feed intake, weight gain, and feed conversion ratio and up to $15 \%$ of the total ration DM for Holstein dairy cows (Donkin et al., 2007) without deleterious effects on milk production or composition. Glycerin has been fed to early postpartum dairy cows (Fisher et al., 1973; DeFrain et al., 2004; Ogborn, 2006) or cows in early (Fisher et al., 1971) to midlactation (Khalili et al., 1997) as an energy supplement rather than as a major feed ingredient. Glycerin, when fed as a glucogenic supplement, did not improve milk yield when compared with propylene glycol (Fisher et al., 1971, 1973) or when it was substi- 
tuted for barley (Khalili et al., 1997). More recent studies (DeFrain et al., 2004; Ogborn, 2006), in which glycerol was fed as an energy supplement to periparturient dairy cows, also revealed no improvement in lactational response from glycerol supplementation.

Glycerol administered by feeding, relative to drenching, generally does not escape fermentation by ruminal microorganisms to acetate, propionate, and butyrate (Czerkawski and Breckenridge, 1972; Remond et al., 1993). Glycerin administered by feeding (DeFrain et al., 2004; Ogborn, 2006) appeared to be less glucogenic than glycerol that was orally drenched or provided via an esophageal pump (Goff and Horst, 2001; Stokes et al., 2002; Linke et al., 2004). Oral drenching and esophageal pumping, however, present tremendous stress to dairy cows, especially in the early postpartum period.

Economic decisions regarding the use of glucogenic substrates in postpartum diets will need to rely not only on lactation responses, but also on benefits to cow health, such as enhanced glucogenic delivery and subsequently lower susceptibility to ketosis. Improved overall energy status or energy availability by supplementing glucogenic substrates is beneficial, although it does not always translate into production performance. Energy status is defined as energy availability that can be assessed by profiling concentrations of key blood metabolites and insulin and urine ketones. Although rumen degradation of glycerin is inevitable, we hypothesized that the energy status of dairy cows in negative energy balance immediately after calving or in early lactation can be improved by propionate produced in the rumen from the fermentation of glycerin. Our objectives were therefore to study the effects on feed intake and milk yield of top dressing glycerin as a dry product to Holstein dairy cows for the first $3 \mathrm{wk}$ of lactation. The responses of feed intake and milk yield were monitored for an additional 3 wk after dry glycerin was removed.

\section{MATERIALS AND METHODS}

\section{Experimental Design and Care of Animals}

Thirty-nine multiparous Holstein dairy cows were balanced for lactation number, previous 305-d matureequivalent milk production, and expected calving date and blocked into 2 groups. Cows were moved from their maternity pen into a naturally ventilated tie-stall barn after calving. Cows were milked twice daily at approximately 0630 and $1830 \mathrm{~h}$, and from parturition to 21 DIM they received a common TMR (Table 1) once daily after the morning milking, which was supplemented (glycerin treatment) or not supplemented (control treatment) with $250 \mathrm{~g} / \mathrm{d}$ of a dry glycerin product containing a minimum of $65 \%$ food grade glycerol (providing 162.5 $\mathrm{g}$ of pure glycerol/d) as a top dressing. The TMR was
Table 1. Ingredient and nutrient composition of the basal TMR

\begin{tabular}{|c|c|}
\hline Ingredient, \% of DM & Mean \\
\hline Corn silage & 26.52 \\
\hline Alfalfa haylage & 20.49 \\
\hline Ground corn & 19.84 \\
\hline Soybeans, roasted & 8.66 \\
\hline Liquid molasses & 4.31 \\
\hline Cookie meal & 3.88 \\
\hline Cottonseed hulls & 3.80 \\
\hline Canola meal & 3.75 \\
\hline Mineral and vitamin premix ${ }^{1}$ & 3.32 \\
\hline Alfalfa hay & 3.01 \\
\hline Soybean meal, heat-treated ${ }^{2}$ & 2.42 \\
\hline Chemical composition & Mean \pm SD \\
\hline $\mathrm{DM}, \%$ & $56.56 \pm 3.11$ \\
\hline $\mathrm{CP}, \%$ of $\mathrm{DM}$ & $16.00 \pm 0.10$ \\
\hline Adjusted protein, $\%$ of $\mathrm{DM}$ & $16.00 \pm 0.10$ \\
\hline Soluble protein, \% of CP & $34.13 \pm 2.64$ \\
\hline Degradable protein, \% of CP & $67.07 \pm 1.32$ \\
\hline Total digestible nutrients, $\%$ of DM & $70.57 \pm 1.40$ \\
\hline $\mathrm{NE}_{\mathrm{L}},{ }^{3} \mathrm{Mcal} / \mathrm{kg}$ & $1.62 \pm 0.03$ \\
\hline $\mathrm{ADF}, \%$ of $\mathrm{DM}$ & $24.33 \pm 0.98$ \\
\hline $\mathrm{NDF}, \%$ of DM & $35.77 \pm 3.25$ \\
\hline Ash, \% of DM & $7.37 \pm 0.78$ \\
\hline $\mathrm{NFC}^{4} \%$ of $\mathrm{DM}$ & $37.70 \pm 2.95$ \\
\hline $\mathrm{Ca}, \%$ of $\mathrm{DM}$ & $0.86 \pm 0.12$ \\
\hline $\mathrm{P}, \%$ of $\mathrm{DM}$ & $0.40 \pm 0.02$ \\
\hline $\mathrm{Mg}, \%$ of $\mathrm{DM}$ & $0.33 \pm 0.02$ \\
\hline $\mathrm{K}, \%$ of $\mathrm{DM}$ & $1.69 \pm 0.04$ \\
\hline $\mathrm{Na}, \%$ of $\mathrm{DM}$ & $0.29 \pm 0.03$ \\
\hline $\mathrm{Fe}, \mathrm{ppm}$ & $241.00 \pm 3.61$ \\
\hline $\mathrm{Mn}, \mathrm{ppm}$ & $88.00 \pm 10.54$ \\
\hline $\mathrm{Zn}, \mathrm{ppm}$ & $104.00 \pm 30.51$ \\
\hline $\mathrm{Cu}, \mathrm{ppm}$ & $26.00 \pm 4.36$ \\
\hline
\end{tabular}

${ }^{1}$ Premix contained $0.296 \%$ of sulfur, $7.183 \mathrm{ppm}$ of selenium, 4.7 $\mathrm{ppm}$ of cobalt, $11.76 \mathrm{ppm}$ of iodine, $21.1 \mathrm{ppm}$ of vitamin A, 438.56 $\mathrm{ppb}$ of vitamin D, and $685.887 \mathrm{ppm}$ of vitamin $\mathrm{E}$.

${ }^{2}$ Amino Plus (Ag Processing Inc., Omaha, NE).

${ }^{3}$ Estimated based on NRC (2001).

${ }^{4} \mathrm{NFC}=100-(\% \mathrm{CP}+\% \mathrm{NDF}+\% \mathrm{ash}+\%$ ether extract $)$.

formulated based on NRC (2001) guidelines for milking Holstein dairy cows at $660 \mathrm{~kg}$ of BW and producing $41 \mathrm{~kg}$ of milk/d with $3.7 \%$ of milk fat. Dry glycerin (Phoderush, Phodé S.A., Albi Terssac, France; $\mathrm{NE}_{\mathrm{L}}=$ $2.6 \mathrm{Mcal} / \mathrm{kg}$ of $\mathrm{DM}$ ) contained $33 \%$ ash, $<2 \%$ glycerin fatty acid esters, $<2 \%$ water, negligible amounts of salt and methanol, and flavoring substances other than glycerol and was stabilized on a dry mineral carrier. The total amount of glycerol $(\sim 3 \mathrm{~kg})$ that was fed as dry glycerin for the duration of the current study was based on the total amount of glycerol ( $3 \mathrm{~L} ; 1.5 \mathrm{~L} /$ drench at $<6$ and $24 \mathrm{~h}$ postcalving) that was esophageally pumped by Stokes et al. (2002), in which blood BHBA was significantly reduced by glycerol. Dry glycerin fed in the current study was used as a glucogenic supplement to provide additional glucogenic substrates to dairy cows in the early postpartum period; therefore, no adjustment in energy concentration was made in the control cow diet to represent the feeding condition in 
the field. Cows were housed at the Pennsylvania State University Dairy Cattle Research and Education Center and allowed out for exercise for $2 \mathrm{~h}$ in an open dry lot before each milking. The experiment was conducted from September 2006 to January 2007. This study was approved by the Pennsylvania State University Institutional Animal Care and Use Committee.

\section{Measurements and Collection of Samples}

Calf birth weight was recorded and calving difficulty evaluated based on a 5-point scale $(1=$ no assistance and 5 = caesarean; National Association of Animal Breeders). The health status of each cow was monitored and recorded on a daily basis. Metabolic and healthrelated disorders were diagnosed and treated by the veterinarian as needed according to Pennsylvania State University Veterinary Standard Operating Procedures. Individual feed intake and milk yield were recorded daily from parturition through 42 DIM. Samples of the TMR were collected weekly and stored at $-20^{\circ} \mathrm{C}$ for chemical analysis. Milk from individual cows was sampled once per week from 2 consecutive milkings for the first $3 \mathrm{wk}$ of lactation. Milk samples were preserved with 2-bromo-2-nitropropane-1,3-diol and analyzed for components. Body condition score was evaluated weekly by 2 individuals based on a 5 -point scale (Wildman et al., 1982). Body weight was recorded daily after each milking. The level of urine acetoacetate was measured and individual blood was collected approximately $2 \mathrm{~h}$ after the morning feeding on 4 ( $\pm 0.49 \mathrm{SD}), 7( \pm 0.92$ $\mathrm{SD}), 14( \pm 0.69 \mathrm{SD})$, and 21 ( $\pm 0.48 \mathrm{SD}) \mathrm{d}$ of parturition. The level of urine acetoacetate was measured from a flowing stream of urine in which a Ketostix (Ketostix, Bayer Corp., Elkhart, IN) was immersed. Blood samples were collected via venipuncture of the coccygeal vein into evacuated tubes (Becton Dickinson, Rutherford, NJ). Blood tubes $(7 \mathrm{~mL})$, which contained potassium oxalate and $4 \%$ sodium fluoride, were used for collecting plasma for analysis of glucose concentration. Blood tubes $(10 \mathrm{~mL})$, which contained sodium heparin, were used for collecting plasma for analyses of BHBA, NEFA, and BUN concentrations. Blood tubes (serum separator tubes; $13 \mathrm{~mL}$ ), which contained clot activator, were used to collect serum for analysis of insulin concentration. Blood tubes were transported on ice to the laboratory within $1 \mathrm{~h}$ after sampling. Plasma was separated from whole blood by centrifuging blood tubes at 3,000 $\times g$ for 15 min at $4^{\circ} \mathrm{C}$. Blood tubes for serum collection were allowed to sit for approximately $0.5 \mathrm{~h}$ and centrifuged at room temperature at $1,000 \times g$ for $15 \mathrm{~min}$ to separate serum. All plasma and serum samples were stored frozen at $-20^{\circ} \mathrm{C}$ until further analyses.

\section{Laboratory Analyses}

Samples of stored TMR were thawed at room temperature and dried for $48 \mathrm{~h}$ at $55^{\circ} \mathrm{C}$ in a forced-air oven and ground in a Wiley mill through a 1-mm screen (A. H. Thomas, Philadelphia, PA). Samples of TMR were composited by month and analyzed for DM, CP, ADF, and minerals by wet chemistry following AOAC (2000) procedures and for NDF following the method of Goering and Van Soest (1970; Cumberland Valley Analytical Services Inc., Maugansville, MD). Nutrient composition of the basal TMR is reported in Table 1. Milk samples were analyzed for fat, true protein, lactose, SCC, and MUN by the Pennsylvania DHIA (University Park, PA) by using infrared spectrophotometry (Fossomatic 4000 Milko-Scan, Foss Electric, Hillerød, Denmark) according to AOAC (1997) procedures. Plasma samples were analyzed for concentrations of glucose (Glucose Test, procedure no. 1075, Stanbio Laboratory Inc., Boerne, TX) based on the method of Trinder (1969), for BHBA (LiquiColor Test procedure no. 2440, Stanbio Laboratory Inc.) based on the method of Williamson et al. (1962), for NEFA (NEFA C Assay Kit, Wako Chemicals USA Inc., Richmond, VA) with the modification of Johnson and Peters (1993), and for BUN (Urea Nitrogen Kit procedure no. 0580, Stanbio Laboratory Inc.) based on the methods of Marsh et al. (1965) and Crocker (1967). Serum samples were analyzed for concentrations of insulin by using an RIA (Coat-A-Count Insulin Kit no. TKINX; Diagnostic Products Corp., Los Angeles, CA).

\section{Calculations}

Net energy balance was calculated for each cow. Net energy intake $\left(\mathbf{N E}_{\mathbf{I}} ; \mathbf{M c a l} / \mathrm{d}\right)$ was calculated by multiplying the DMI by the calculated energy density of the diet. The extra energy provided by dry glycerin $(0.42$ $\mathrm{Mcal} / \mathrm{d}$ ) was included in $\mathrm{NE}_{\mathrm{I}}$. Net energy required for body maintenance $\left(\mathrm{NE}_{\mathrm{M}} ; \mathrm{Mcal} / \mathrm{d}\right)$ was calculated as $\mathrm{BW}^{0.75} \times 0.08(\mathrm{NRC}, 2001)$. Net energy required for milk production $\left(\mathrm{NE}_{\mathrm{L}} ; \mathrm{Mcal} / \mathrm{d}\right)$ was calculated as milk yield $(\mathrm{kg}) \times[(0.0929 \times$ fat $\%)+(0.0563 \times$ protein $\%)+(0.0395$ $\times$ lactose \%)] (NRC, 2001). Estimated energy balance was calculated as $\mathrm{NE}_{\mathrm{I}} \div\left(\mathrm{NE}_{\mathrm{M}}+\mathrm{NE}_{\mathrm{L}}\right) \times 100$ and expressed as percentage of the requirement. Change in BW was calculated as the difference between the average BW of 1 to 3 DIM to the average BW of 19 to 21 DIM. Change in BCS was calculated as the difference between the average BCS at wk 1 to the average BCS at wk 3 of lactation.

\section{Statistical Analysis}

The experiment was conducted as a completely randomized block design by using lactation number, previ- 
Table 2. Allocation, calf birth weight, and calving difficulty for multiparous Holstein dairy cows not supplemented or supplemented with $250 \mathrm{~g} / \mathrm{d}$ of dry glycerin from parturition to $21 \mathrm{~d}$ postpartum

\begin{tabular}{lcccc}
\hline & \multicolumn{2}{c}{ Treatment } & & \\
\cline { 2 - 3 } Variable & Control & Glycerin & SEM & $\begin{array}{c}P \text {-value, } \\
\text { treatment }\end{array}$ \\
\hline Cows, $\mathrm{n}$ & 19 & 20 & & \\
Lactation number & 2.0 & 2.4 & 0.29 & 0.34 \\
305-d mature-equivalent production, $\mathrm{kg}$ & 12,942 & 13,548 & 632.9 & 0.50 \\
Calf birth weight, kg $^{\text {Calving difficulty score }}{ }^{1}$ & 46.99 & 45.64 & 1.85 & 0.60 \\
\hline
\end{tabular}

${ }^{1}$ Five-point scale: 1 = no assistance, 2 = slight problem, 3 = needed assistance, 4 = considerable force, and 5 = caesarean (National Association of Animal Breeders).

ous 305-d mature-equivalent milk production, and expected calving date as blocking criteria. Data for cows that had health-related disorders for the duration of the trial were examined for abnormalities. Data from these cows were not hindered by disorders and were therefore kept in the data set. Milk yield for the first $3 \mathrm{~d}$ of lactation was excluded to avoid sampling of colostrum, and corresponding DMI were also excluded. Before statistical analysis, daily measurements for DMI, milk production, and BW were condensed to weekly averages. Data were analyzed as repeated measures by using PROC MIXED (SAS Institute, 1999). The general linear mixed model was:

$$
\mathrm{y}_{\mathrm{ijk}}=\mu+\alpha_{\mathrm{i}}+\beta_{\mathrm{j}}+(\alpha \beta)_{\mathrm{ij}}+\gamma(\alpha)_{\mathrm{ik}}+\varepsilon_{\mathrm{ijk}}
$$

where $\mathrm{y}_{\mathrm{ijk}}$ is the observation on cow $\mathrm{k}$ at sampling time j given treatment $\mathrm{i} ; \mu$ is the overall mean; $\alpha_{\mathrm{i}}$ is the fixed effect of treatment $\mathrm{i}$ (control or glycerin); $\beta_{\mathrm{j}}$ is the fixed effect of sampling time $\mathrm{j}$ ( $\mathrm{d}$ or wk); $(\alpha \beta)_{\mathrm{ij}}$ is the 2 -way interaction of treatment $\mathrm{i}$ by sampling time $\mathrm{j}$; and $\gamma(\alpha)_{\mathrm{ik}}$ is the random effect of cow $\mathrm{k}$ nested within treatment i. The residual terms $\varepsilon_{\mathrm{ijk}}$ are assumed to be normally, independently, and identically distributed with variance $\sigma_{\mathrm{e}}^{2}$. Degrees of freedom were estimated by using the Kenward-Roger option in the MODEL statement (Kenward and Roger, 1997). Time of sampling (day or week) was used in the REPEATED statement. Timeseries covariance structure was modeled by using the options of autoregressive order one, compound symmetry, and unstructured and spatial power law (Littell et al., 1996; Bryant et al., 1999). The best time-series covariance structure was selected based on the lowest Akaike and Bayesian information criteria (Littell et al., 1998). The PDIFF option was used for multiplecomparison tests. Data are presented as means \pm standard deviations or least squares means \pm standard errors of the means. Statistical significance was declared at $P \leq 0.05$ and a tendency to significance was declared at $0.05<P \leq 0.15$.

\section{RESULTS}

Allocation of cows, calf birth weights, and calving difficulties are reported in Table 2. Cows that were distributed into groups were statistically similar in production level from the previous lactation. Incidences of health-related disorders were similar between treatments and were comparable to average herds (Table 3 ). Because of the low number of cows per group, it is not possible to draw conclusions regarding the effects of dry glycerin on the incidence of any health-related disorder.

Dry matter intake, milk yield, and the efficiency of converting feed into milk are reported in Table 4. Dry matter intake and milk yield increased as lactation progressed but did not differ significantly between treatments (Figures 1 and 2). Yield of milk started to diverge after the glycerin top dressing was terminated, and this divergence in milk yield became most noticeable at wk 6 of lactation ( $46 \mathrm{vs} .52 \mathrm{~kg} / \mathrm{d}$, for the control and glycerin treatments, respectively; $P=0.14$ ). Glycerin-supplemented cows showed a trend $(P=0.15)$ toward higher efficiency of converting feed into milk during the 6 -wk period. This higher efficiency of converting feed into milk observed in glycerin-supplemented cows was most notable during wk 4 to 6 of lactation after glycerin was no longer top dressed $(P=0.06$; Figure 3$)$.

Table 3. Incidences of health-related disorders for multiparous Holstein dairy cows not supplemented or supplemented with $250 \mathrm{~g} / \mathrm{d}$ of dry glycerin from parturition to $21 \mathrm{~d}$ postpartum

\begin{tabular}{lccc}
\hline & \multicolumn{2}{c}{ Treatment } & \\
\cline { 2 - 3 } Variable & Control & Glycerin & $P$-value \\
\hline Twinning & 1 & 1 & 1.00 \\
Ketosis & 1 & 0 & 0.49 \\
Displaced abomasum & 1 & 1 & 1.00 \\
Retained placenta & 2 & 2 & 1.00 \\
Metritis & 0 & 3 & 0.23 \\
Mastitis & 2 & 4 & 0.66 \\
Fever & 0 & 3 & 0.23 \\
Multiple disorders & 2 & 5 & 0.41 \\
\hline
\end{tabular}

${ }^{1}$ Fisher's exact test. 
Table 4. Dry matter intake and milk yield for multiparous Holstein dairy cows not supplemented or supplemented with $250 \mathrm{~g} / \mathrm{d}$ of dry glycerin from parturition to $21 \mathrm{~d}$ postpartum

\begin{tabular}{|c|c|c|c|c|c|c|}
\hline \multirow[b]{2}{*}{ Variable } & \multicolumn{2}{|c|}{ Treatment } & \multirow[b]{2}{*}{ SEM } & \multicolumn{3}{|c|}{$P$-value } \\
\hline & Control & Glycerin & & Treatment & Week & Treatment $\times$ week \\
\hline \multicolumn{7}{|l|}{$\mathrm{DMI},{ }^{1} \mathrm{~kg} / \mathrm{d}$} \\
\hline Week 1 to 3 & 20.92 & 19.18 & 1.08 & 0.25 & $<0.01$ & 1.00 \\
\hline Week 4 to 6 & 25.47 & 25.15 & 0.85 & 0.79 & $<0.01$ & 0.43 \\
\hline Week 1 to 6 & 23.18 & 22.15 & 0.91 & 0.42 & $<0.01$ & 0.62 \\
\hline \multicolumn{7}{|l|}{ DMI, \% of BW } \\
\hline Week 1 to 3 & 3.18 & 3.01 & 0.16 & 0.45 & $<0.01$ & 0.89 \\
\hline Week 4 to 6 & 3.88 & 3.98 & 0.12 & 0.52 & $<0.01$ & 0.29 \\
\hline Week 1 to 6 & 3.53 & 3.49 & 0.13 & 0.85 & $<0.01$ & 0.50 \\
\hline \multicolumn{7}{|c|}{ Milk yield ${ }^{1} \mathrm{~kg} / \mathrm{d}$} \\
\hline Week 1 to 3 & 38.25 & 39.11 & 1.96 & 0.75 & $<0.01$ & 0.86 \\
\hline Week 4 to 6 & 46.01 & 50.04 & 2.36 & 0.23 & $<0.01$ & 0.22 \\
\hline Week 1 to 6 & 42.14 & 44.57 & 2.07 & 0.41 & $<0.01$ & 0.54 \\
\hline \multicolumn{7}{|l|}{ Feed efficiency ${ }^{2}$} \\
\hline Week 1 to 3 & 2.00 & 2.13 & 0.11 & 0.40 & 0.11 & 0.87 \\
\hline Week 4 to 6 & 1.83 & 2.01 & 0.07 & 0.06 & 0.06 & 0.59 \\
\hline Week 1 to 6 & 1.91 & 2.07 & 0.08 & 0.15 & 0.09 & 0.95 \\
\hline
\end{tabular}

\footnotetext{
${ }^{1}$ Milk yield from 0 to 3 DIM was excluded to avoid sampling of colostrum; therefore, DMI from 0 to 3 DIM were not included.

${ }^{2}$ Feed efficiency $=$ milk yield $(\mathrm{kg} / \mathrm{d}) \div$ DMI $(\mathrm{kg} / \mathrm{d})$.
}

Body weights, BCS, changes in BW and BCS, and energy balance are reported in Table 5 . Body weights decreased as lactation progressed, reflecting the mobilization of body reserves, as indicated by the negative energy balance. Both groups of cows showed similar reductions in BW. The average energy balance, when expressed as a percentage of the requirement, tended to be lower for glycerin-supplemented cows in the first week of lactation ( $74 \mathrm{vs.} 89 \%$ for the glycerin and control treatment, respectively; $P=0.06$ ). Unlike what is usually observed, BCS did not significantly decrease $(P=$ 0.26 ) with time until after the first 3 wk into lactation.
When comparing BCS between treatments, control cows tended (wk 1 to $5, P=0.15$ ) to have higher BCS than glycerin-supplemented cows, but this difference in BCS already existed beginning in the first week of lactation and was carried over the entire observational period with the same degree of reduction in BCS between treatments. All cows that were used in this study started off the trial with a normal body condition (control, $\mathrm{BCS}=3.2$; glycerin, $\mathrm{BCS}=3.1$, and the cows lost a reasonable amount of BW and minimal BCS (Hutjens, 1996) during the first $3 \mathrm{wk}$ of lactation.

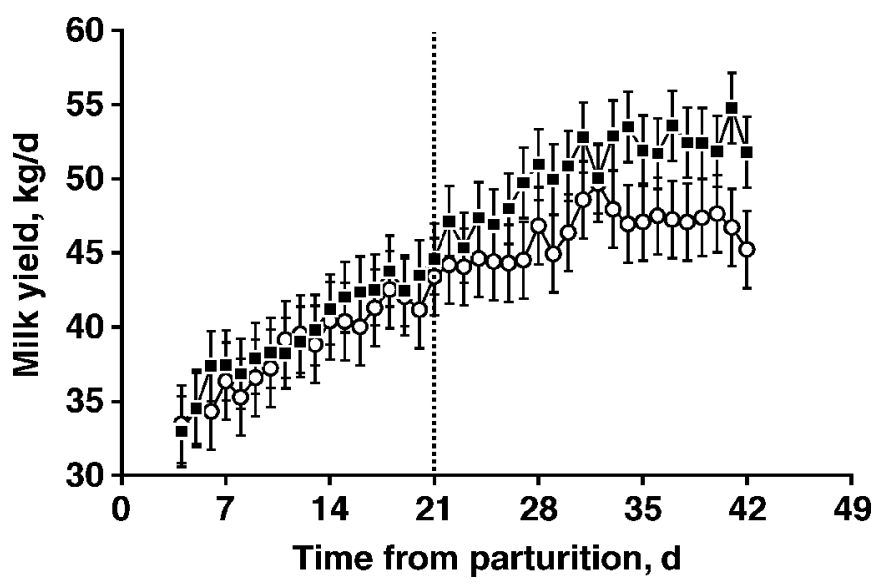

Figure 2. Milk yield for multiparous Holstein dairy cows not supplemented $(\bigcirc)$ or supplemented with (ם) $250 \mathrm{~g} / \mathrm{d}$ of dry glycerin from parturition to $21 \mathrm{~d}$ postpartum. Pooled SEM $=2.60$. Wk 1 to 6 : treatment, $P=0.41$; week, $P<0.01$; treatment $\times$ week, $P=0.54$. The dotted line indicates the termination of dry glycerin feeding.
Figure 1. Dry matter intake for multiparous Holstein dairy cows not supplemented $(\bigcirc)$ or supplemented with $(\square) 250 \mathrm{~g} /$ d of dry glycerin from parturition to $21 \mathrm{~d}$ postpartum. Pooled $\mathrm{SEM}=1.56$. Wk 1 to 6 : treatment, $P=0.42$; week, $P<0.01$; treatment $\times$ week, $P=0.62$. The dotted line indicates the termination of dry glycerin feeding. 


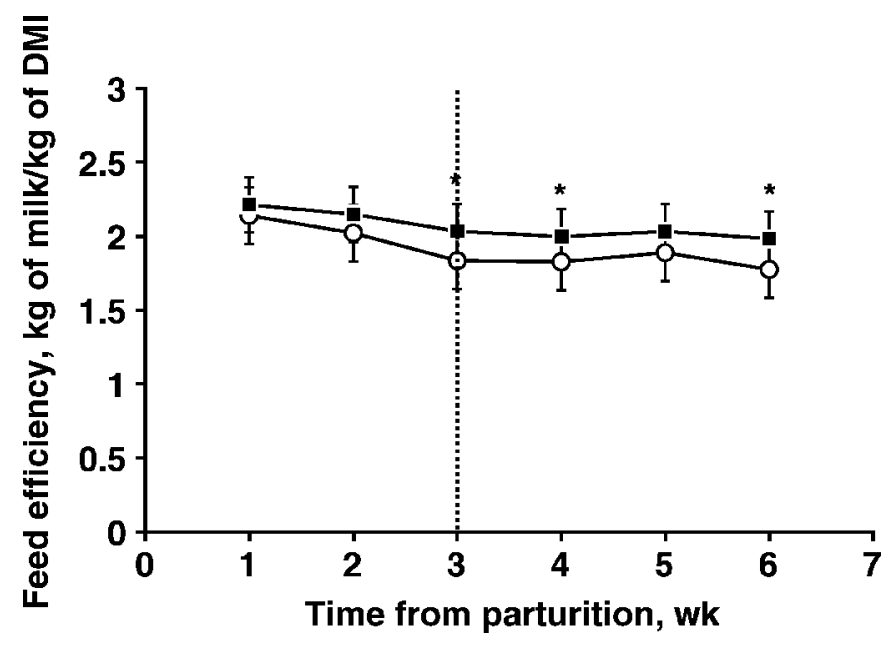

Figure 3. Feed efficiency for multiparous Holstein dairy cows not supplemented $(\bigcirc)$ or supplemented with (ロ) $250 \mathrm{~g} / \mathrm{d}$ of dry glycerin from parturition to $21 \mathrm{~d}$ postpartum. Pooled $\mathrm{SEM}=0.19$. Wk 1 to 6 : treatment, $P=0.15$; week, $P=0.09$; treatment $\times$ week, $P=0.95$. Tendency to significance: $* 0.05<P \leq 0.15$. The dotted line indicates the termination of dry glycerin feeding.

The $4 \% \mathrm{FCM}$ yield, efficiency of converting feed into $4 \%$ FCM production, and percentages and yields of milk components are reported in Table 6. Percentage of milk fat tended to be lower $(P=0.07)$ and decreased at a faster rate $(P=0.07)$ in glycerin-supplemented cows than in control cows, and the effect of glycerin on milk fat percentage was significant during wh 2 and 3 of lactation. Yields of milk components and $4 \%$ FCM, however, did not differ between treatments. This effect of glycerin on milk fat percentage was a result of numerically higher milk yields together with numerically lower milk fat yields during wk 2 and 3 of lactation although yields of milk, milk components, and 4\% FCM did not differ between treatments.

Concentrations of plasma metabolites, serum insulin, and urine ketones are reported in Table 7. Overall, glycerin did not significantly affect any plasma metabolite, serum insulin, or urine ketones. Tendencies toward significant treatment $\times$ time interactions were observed for concentrations of insulin $(P=0.06$; Figure 4$)$, NEFA $(P=0.11$; Figure 5), and urine ketones $(P=0.14)$. The overall treatment $\times$ time interactions for the duration of the trial found in insulin, NEFA, and urine ketones were due to the glycerin-supplemented cows having significantly lower $(P=0.05)$ insulin and numerically higher NEFA concentrations $(P=0.14)$ at 4 DIM and numerically lower urine ketone concentrations at 4 and 14 DIM ( $P=0.11$ and $P=0.08$ for 4 and 14 DIM, respectively). The glycerin-supplemented cows tended to mobilize more body reserves than the control cows at 4 DIM. Although no significant overall treatment $\times$ time interaction was observed, concentrations of plasma glucose $(P=0.15$; Figure 6$)$ tended to be higher and BHBA ( $P=0.10$; Figure 7$)$ lower at 14 DIM for glycerin-supplemented cows.

\section{DISCUSSION}

Dry glycerin fed as a top dressing in this study did not act as an appetite stimulant for lactating dairy cows in early lactation, as previous studies had indicated (Fisher et al., 1971). In the study by Fisher et al. (1971), the concentrate intake of cows was statistically higher when glycerol was incorporated into the concentrate, rather than propylene glycol. The concentrate intake of cows did not differ when glycerol, succinate, or glutamine was incorporated into the concentrate, and there

Table 5. Body weight, BW change, BCS, and BCS change for multiparous Holstein dairy cows not supplemented or supplemented with $250 \mathrm{~g} / \mathrm{d}$ of dry glycerin from parturition to $21 \mathrm{~d}$ postpartum

\begin{tabular}{|c|c|c|c|c|c|c|}
\hline \multirow[b]{2}{*}{ Variable } & \multicolumn{2}{|c|}{ Treatment } & \multirow[b]{2}{*}{ SEM } & \multicolumn{3}{|c|}{$P$-value } \\
\hline & Control & Glycerin & & Treatment & Week & Treatment $\times$ week \\
\hline $\mathrm{BW}$ wk 1 to $3, \mathrm{~kg}$ & 671 & 640 & 17.82 & 0.22 & $<0.01$ & 0.70 \\
\hline BW change, ${ }^{1} \mathrm{~kg}$ & -36.6 & -36.1 & 8.34 & 0.97 & $\mathrm{NA}^{2}$ & NA \\
\hline BCS wk 1 to 3 & 3.17 & 3.08 & 0.05 & 0.17 & 0.26 & 0.86 \\
\hline BCS change $^{3}$ & -0.02 & -0.04 & 0.03 & 0.60 & NA & NA \\
\hline \multicolumn{7}{|l|}{ Energy balance ${ }^{4}$} \\
\hline$\%$ of requirement & 90.08 & 82.12 & 4.27 & 0.18 & 0.02 & 0.25 \\
\hline $\mathrm{Mcal} / \mathrm{d}$ & -4.79 & -7.40 & 1.64 & 0.25 & 0.01 & 0.41 \\
\hline
\end{tabular}

\footnotetext{
${ }^{1}$ Body weight change was calculated as the difference between the average BW of 1 to 3 DIM to 19 to 21 DIM.

${ }^{2} \mathrm{NA}=$ not applicable.

${ }^{3}$ Body condition score change was calculated as the difference between the average BCS of wk 1 to 3 of lactation.

${ }^{4}$ Energy balance $=\left[\mathrm{NE}_{\mathrm{I}} \div\left(\mathrm{NE}_{\mathrm{M}}+\mathrm{NE}_{\mathrm{L}}\right) \times 100\right]$ as a percentage of the requirement or $\left[\mathrm{NE}_{\mathrm{I}} \div\left(\mathrm{NE}_{\mathrm{M}}+\mathrm{NE}_{\mathrm{L}}\right)\right]$ as Mcal/d. Net energy intake $\left(\mathrm{NE}_{\mathrm{I}}\right)=\mathrm{DMI} \times$ dietary $\mathrm{NE}_{\mathrm{L}}+\mathrm{NE}_{\mathrm{L}}$ from glycerin. $\mathrm{NE}_{\mathrm{M}}=\mathrm{BW}^{0.75} \times 0.08 . \mathrm{NE}_{\mathrm{L}}=$ milk yield $(\mathrm{kg}) \times[(0.0929 \times$ fat $\%)+(0.0563 \times$ protein $\%)+(0.0395 \times$ lactose $\%)]$
} 
Table 6. Yield and efficiency of $4 \%$ FCM and yield of milk components for multiparous Holstein dairy cows not supplemented or supplemented with $250 \mathrm{~g} / \mathrm{d}$ of dry glycerin from parturition to $21 \mathrm{~d}$ postpartum

\begin{tabular}{|c|c|c|c|c|c|c|}
\hline \multirow[b]{2}{*}{ Variable } & \multicolumn{2}{|c|}{ Treatment } & \multirow[b]{2}{*}{ SEM } & \multicolumn{3}{|c|}{$P$-value } \\
\hline & Control & Glycerin & & Treatment & Week & Treatment $\times$ week \\
\hline $4 \% \mathrm{FCM},{ }^{1} \mathrm{~kg} / \mathrm{d}$ & 41.72 & 42.04 & 2.16 & 0.92 & 0.31 & 0.66 \\
\hline $4 \%$ FCM efficiency ${ }^{2}$ & 2.05 & 2.22 & 0.13 & 0.34 & 0.01 & 0.60 \\
\hline Fat, \% & 4.37 & 4.00 & 0.14 & 0.07 & $<0.01$ & 0.07 \\
\hline Fat yield, kg/d & 1.72 & 1.67 & 0.09 & 0.68 & 0.46 & 0.41 \\
\hline Protein, \% & 3.19 & 3.09 & 0.05 & 0.17 & $<0.01$ & 0.81 \\
\hline Protein yield, kg/d & 1.28 & 1.30 & 0.04 & 0.77 & 0.82 & 0.46 \\
\hline Lactose, \% & 4.66 & 4.60 & 0.06 & 0.49 & $<0.01$ & 0.68 \\
\hline Lactose yield, $\mathrm{kg} / \mathrm{d}$ & 1.89 & 1.98 & 0.12 & 0.59 & $<0.01$ & 0.62 \\
\hline SCC, 1,000 cells $/ \mathrm{mL}$ & 191 & 335 & 138.4 & 0.46 & 0.63 & 0.66 \\
\hline SCC, linear score & 2.56 & 2.46 & 0.37 & 0.85 & 0.34 & 0.54 \\
\hline MUN, mg/dL & 13.17 & 13.31 & 0.41 & 0.82 & 0.12 & 0.35 \\
\hline
\end{tabular}

${ }^{1} 4 \% \mathrm{FCM}=(0.4 \times$ milk yield $)+[15 \times(\%$ fat $\div 100) \times$ milk yield $]$.

${ }^{2} 4 \%$ FCM efficiency $=4 \%$ FCM $(\mathrm{kg} / \mathrm{d}) \div \mathrm{DMI}(\mathrm{kg} / \mathrm{d})$.

was no control in that experiment. Therefore, glycerol maintained, rather than stimulated, the concentrate intake when compared with propylene glycol. The majority of research results have reported no stimulative (DeFrain et al., 2004; Donkin et al., 2007; current study) or depressive (Ogborn, 2006) effects of glycerol on appetite in lactating cows. The inconsistent effects of glycerol on feed intake may be due to the quality of the glycerol product used. Substances such as salts and methanol, which are coproduced during the synthesis of glycerol, may influence the palatability of the final glycerol product. Therefore, purity of the product is critical (Schröder and Südekum, 1999).

Production of milk and 4\% FCM, and percentages and yields of milk components were not significantly affected by dry glycerin in the current study, in agreement with recent (DeFrain et al., 2004; Ogborn, 2006) and previous (Fisher et al., 1973) studies in which glycerol was also fed to early postpartum dairy cows. DeFrain et al. (2004) reported tendencies for a lower milk fat yield and MUN when glycerol was fed. This reduction in glycerol on milk fat yield and MUN, however, was not noted in the current study or in other studies (Fisher et al., 1973; Ogborn, 2006).
The cows used in this experiment transitioned relatively well based on milk production level and energy balance. On average, the cows produced $39 \mathrm{~kg} / \mathrm{d}$ of milk and lost only $36 \mathrm{~kg}$ of BW and 0.03 point (5-point scale) of BCS during the first $3 \mathrm{wk}$ of lactation, as opposed to approximately $60 \mathrm{~kg}$ of $\mathrm{BW}$ and 0.5 point of BCS reduction, which were observed by DeFrain et al. (2004). Plasma concentrations of NEFA and BHBA concur with the relatively minimal mobilization of body fat, as indicated by the reductions in BW and BCS. During the entire sampling period, the plasma level of NEFA or BHBA at any time point did not exceed the cutoff value of the plasma NEFA level of $>500 \mu \mathrm{Eq} / \mathrm{L}$ or the plasma BHBA level of $>1,200 \mu \mathrm{mol} / \mathrm{L}$, which have been proposed as differentiating susceptibility to displaced abomasum or clinical ketosis (LeBlanc et al., 2005), respectively.

A more positive energy status (higher concentrations of plasma glucose, lower concentrations of plasma BHBA, and lower concentrations of urine ketones) was observed at the second week of lactation, although the calculated overall energy balance during the first $3 \mathrm{wk}$ of lactation was numerically lower (79 vs. $88 \%$ of requirement for glycerin-supplemented and control cows,

Table 7. Concentration of plasma metabolites, serum insulin, and urine ketones for multiparous Holstein dairy cows not supplemented or supplemented with $250 \mathrm{~g} / \mathrm{d}$ of dry glycerin from parturition to $21 \mathrm{~d}$ postpartum

\begin{tabular}{|c|c|c|c|c|c|c|}
\hline \multirow[b]{2}{*}{ Variable } & \multicolumn{2}{|c|}{ Treatment } & \multirow[b]{2}{*}{ SEM } & \multicolumn{3}{|c|}{$P$-value } \\
\hline & Control & Glycerin & & Treatment & Week & Treatment $\times$ week \\
\hline BUN, mg/dL & 11.18 & 10.62 & 0.63 & 0.53 & $<0.01$ & 0.18 \\
\hline Glucose, $\mathrm{mg} / \mathrm{dL}$ & 54.51 & 54.80 & 1.12 & 0.85 & $<0.01$ & 0.28 \\
\hline Insulin, $\mu \mathrm{IU} / \mathrm{mL}$ & 5.18 & 4.75 & 0.68 & 0.64 & $<0.01$ & 0.06 \\
\hline NEFA, $\mu \mathrm{Eq} / \mathrm{L}$ & 348.79 & 370.79 & 30.33 & 0.61 & $<0.01$ & 0.11 \\
\hline $\mathrm{BHBA}, \mu \mathrm{mol} / \mathrm{L}$ & 892.40 & 834.37 & 92.04 & 0.65 & $<0.01$ & 0.20 \\
\hline Urine ketones, mg/dL & 17.94 & 6.83 & 5.76 & 0.18 & 0.08 & 0.14 \\
\hline
\end{tabular}




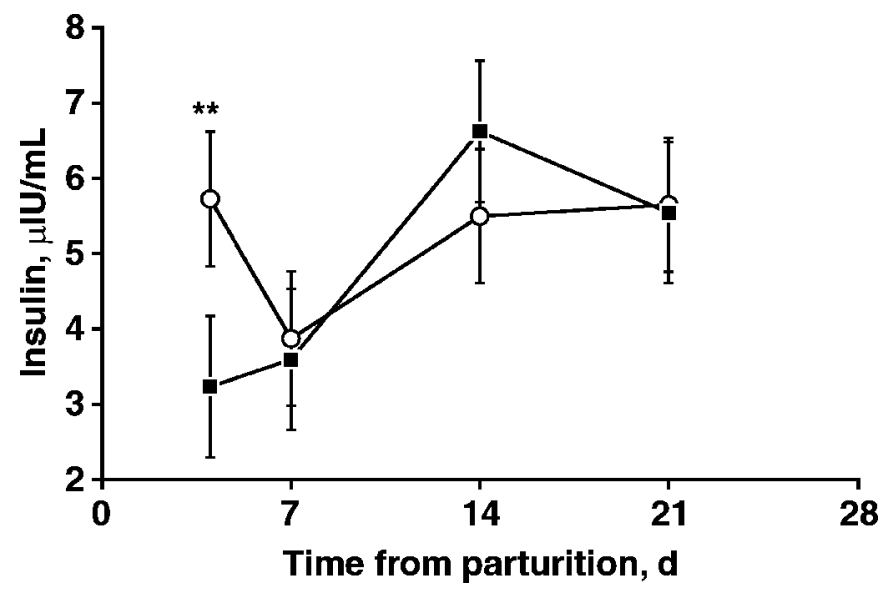

Figure 4. Concentration of serum insulin for multiparous Holstein dairy cows not supplemented $(\bigcirc)$ or supplemented with (ם) $250 \mathrm{~g} / \mathrm{d}$ of dry glycerin from parturition to $21 \mathrm{~d}$ postpartum. Pooled SEM = 0.94 . Treatment, $P=0.64$; day, $P<0.01$; treatment $\times$ day, $P=0.06$. Significance: $* * P \leq 0.05$.

respectively), suggesting that energy availability may have been improved by top dressing dry glycerin. Additional evidence for a glucogenic effect of dry glycerin was the relatively lower contribution of plasma NEFA to milk fat synthesis in the mammary gland. When individual milk fat percentage was regressed to its corresponding plasma NEFA concentration, in control cows $27 \%$ of the variation in milk fat percentage could be explained by plasma NEFA concentration (milk fat $\%=3.34+0.003 \times$ plasma NEFA concentration; $\mathrm{R}^{2}=$ 0.27 and $P<0.01$ ), whereas in glycerin-supplemented

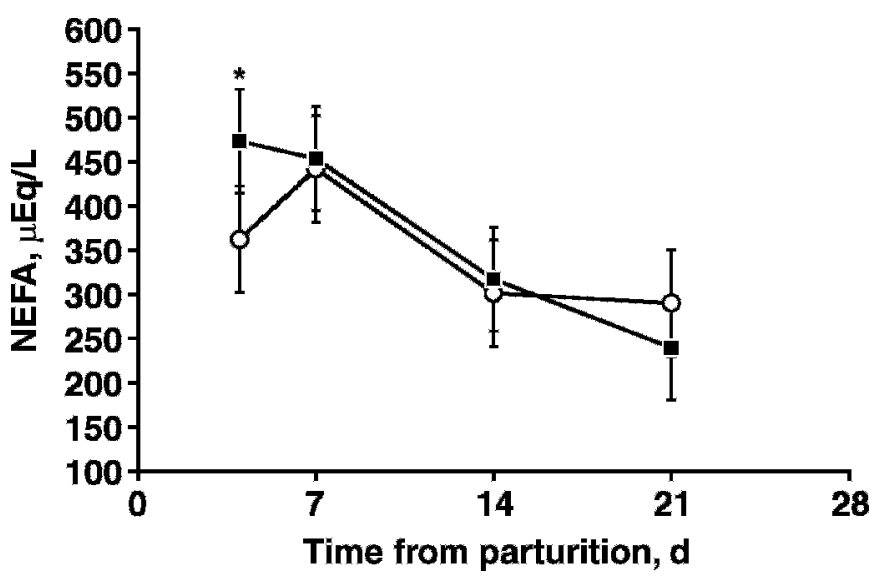

Figure 5. Concentration of plasma NEFA for multiparous Holstein dairy cows not supplemented $(\bigcirc)$ or supplemented with (ם) $250 \mathrm{~g} / \mathrm{d}$ of dry glycerin from parturition to $21 \mathrm{~d}$ postpartum. Pooled SEM = 60.32. Treatment, $P=0.61$; day, $P<0.01$; treatment $\times$ day, $P=0.11$. Tendency to significance: $* 0.05<P \leq 0.15$.

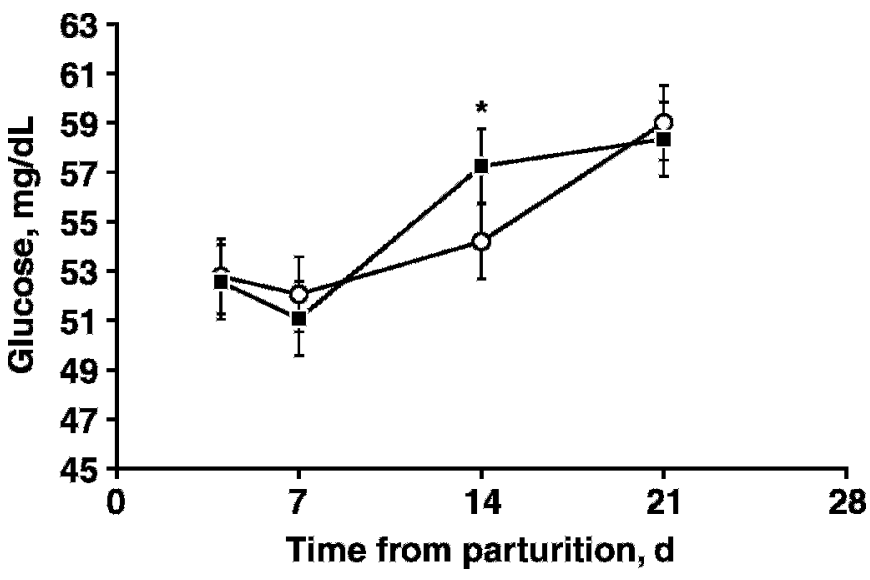

Figure 6. Concentration of plasma glucose for multiparous Holstein dairy cows not supplemented $(\bigcirc)$ or supplemented with (ם) 250 $\mathrm{g} / \mathrm{d}$ of dry glycerin from parturition to $21 \mathrm{~d}$ postpartum. Pooled $\mathrm{SEM}=$ 1.51. Treatment, $P=0.85$; day: $P<0.01$; treatment $\times$ day, $P=0.28$. Tendency to significance: $* 0.05<P \leq 0.15$.

cows, only $6 \%$ of the variation could be explained by plasma NEFA concentration (milk fat $\%=3.55+0.001$ $\times$ plasma NEFA concentration; $\mathrm{R}^{2}=0.06$ and $P<0.05$ ). The numerical increase in milk yield at wk 6 of lactation (52 vs. $46 \mathrm{~kg} / \mathrm{d}$ ) for cows provided dry glycerin during the first $3 \mathrm{wk}$ of lactation may be related to the better energy status for these cows observed during the second week of lactation, which perhaps positioned these cows to handle the negative energy balance better.

The glucogenic property of dry glycerin via feeding at the level studied (162.5 g of glycerol/d) may not have

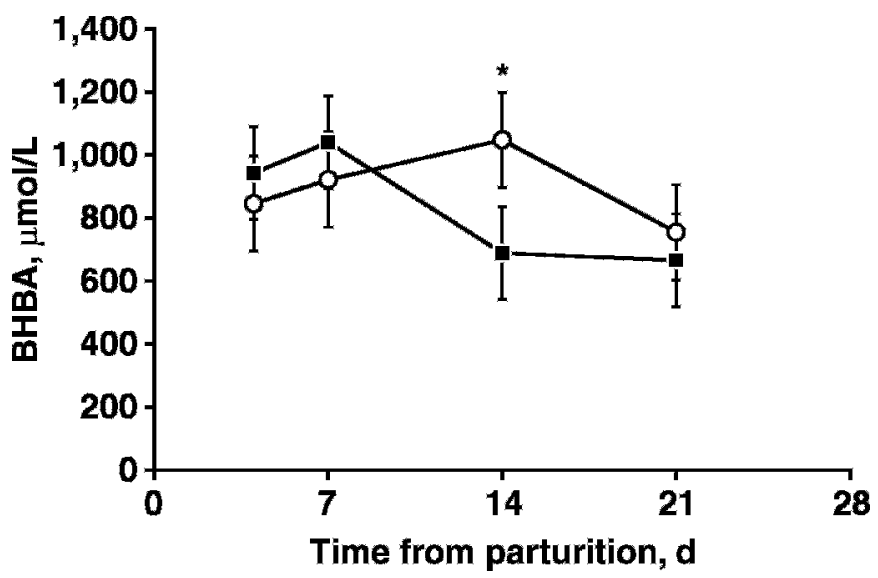

Figure 7. Concentration of plasma BHBA for multiparous Holstein dairy cows not supplemented $(\bigcirc)$ or supplemented with (ם) 250 $\mathrm{g} / \mathrm{d}$ of dry glycerin from parturition to $21 \mathrm{~d}$ postpartum. Pooled $\mathrm{SEM}=$ 151.0. Treatment, $P=0.65$; day, $P<0.01$; treatment $\times$ day, $P=0.20$. Tendency to significance: $* 0.05<P \leq 0.15$. 
been adequate to elicit a milk yield response. It is not known whether the gluconeogenicity of dry glycerin can be translated into higher milk production when dry glycerin is fed at amounts greater than the $860 \mathrm{~g}$ of glycerol/d that was top dressed in the study by DeFrain et al. (2004), in which no improvement in milk yield was reported. Unlike in the study by DeFrain et al. (2004), a pure dry glycerin product was used in this study, and it may have affected the metabolism of early postpartum dairy cows differently than liquid glycerin (or glycerol) based on the better energy status during the supplementation period and the trend for an increase in milk yield and a higher feed efficiency after the supplemental period.

\section{CONCLUSIONS}

Dry glycerin fed as a top dressing at $250 \mathrm{~g} / \mathrm{d}$ (corresponding to $162.5 \mathrm{~g}$ of food grade glycerol/d) to multiparous Holstein dairy cows from parturition to 3 wk into lactation tended to improve energy availability (higher blood glucose, lower blood BHBA, and lower urine ketones) of cows during the second week of lactation. This glucogenic effect of dry glycerin did not result in an increase in feed intake or milk yield during the first 3 wk of lactation, likely because of the relatively less negative energy status, as defined herein, of cows transitioning into lactation. The tendency toward higher milk yield for glycerin-supplemented cows during wk 6 of lactation (52 vs. $46 \mathrm{~kg} / \mathrm{d} ; P=0.14$ ) after the supplementation period (dry glycerin was terminated at wk 3 of lactation) suggested a potential benefit of dry glycerin on subsequent milk production perhaps through changes in metabolism, which requires further investigation.

\section{ACKNOWLEDGMENTS}

Founding was supported in part by Phodé (Albi Terssac, France). Appreciation is expressed to Alejandro Martinez and Kyle S. Heyler for technical assistance and to all personnel at the Pennsylvania State University Dairy Cattle Research and Education Center for feeding and constant care of animals.

\section{REFERENCES}

AOAC. 1997. Official Methods of Analysis. 16th ed. AOAC Int., Gaithersburg, MD.

AOAC. 2000. Official Methods of Analysis. 17th ed. AOAC Int., Gaithersburg, MD.

Bryant, T. C., J. D. Rivera, M. L. Galyean, G. C. Duff, D. M. Hallford, and T. H. Montgomery. 1999. Effects of dietary level of ruminally protected choline on performance and carcass characteristics of finishing beef steers and on growth and serum metabolites in lambs. J. Anim. Sci. 77:2893-2903.
Cori, C. F., and W. M. Shine. 1935. The formation of carbohydrate from glycerophosphate in the liver of the rat. Science 82:134-135.

Crocker, C. L. 1967. Rapid determination of urea nitrogen in serum or plasma without deproteinization. Am. J. Med. Technol. 33:361-365.

Czerkawski, J. W., and G. Breckenridge. 1972. Fermentation of various glycolytic intermediates and other compounds by rumen micro-organisms, with particular reference to methane production. Br. J. Nutr. 27:131-146.

DeFrain, J. M., A. R. Hippen, K. F. Kalscheur, and P. W. Jardon. 2004. Feeding glycerol to transition dairy cows: Effects on blood metabolites and lactation performance. J. Dairy Sci. 87:41954206

Donkin, S. S., M. R. Pallatin, P. H. Doane, M. J. Cecava, H. M. White, E. Barnes, and S. L. Koser. 2007. Performance of dairy cows fed glycerol as a primary feed ingredient. J. Dairy Sci. 90(Suppl. 1):350. (Abstr.)

Fisher, L. J., J. D. Erfle, G. A. Lodge, and F. D. Sauer. 1973. Effects of propylene glycol or glycerol supplementation of the diet of dairy cows on feed intake, milk yield and composition, and incidence of ketosis. Can. J. Anim. Sci. 53:289-296.

Fisher, L. J., J. D. Erfle, and F. D. Sauer. 1971. Preliminary evaluation of the addition of glucogenic materials to the rations of lactating cows. Can. J. Anim. Sci. 51:721-727.

Goering, H. K., and P. J. Van Soest. 1970. Forage Fiber Analysis (Apparatus, Reagents, Procedures and Some Applications). Agric. Handbook No. 379. ARS-USDA, Washington, DC.

Goff, J. P., and R. L. Horst. 2001. Oral glycerol as an aid in the treatment of ketosis/fatty liver complex. J. Dairy Sci. 84(Suppl. 1):153. (Abstr.)

Hutjens, M. F. 1996. Practical approaches to feeding the high producing cow. Anim. Feed Sci. Technol. 59:199-206.

Johnson, M. M., and J. P. Peters. 1993. Technical note: An improved method to quantify nonesterified fatty acids in bovine plasma. J. Anim. Sci. 71:753-756.

Johnson, R. B. 1951. New methods of treating ketosis: A preliminary report. North Am. Vet. 32:327-332.

Johnson, R. B. 1954. The treatment of ketosis with glycerol and propylene glycol. Cornell Vet. 44:6-21.

Kenward, M. G., and J. H. Roger. 1997. Small sample inference for fixed effects from restricted maximum likelihood. Biometrics 53:983-997.

Khalili, H., T. Varvikko, V. Toivonen, K. Hissa, and M. Suvitie. 1997. The effects of added glycerol or unprotected free fatty acids or a combination of the two on silage intake, milk production, rumen fermentation and diet digestibility in cows given grass silage based diets. Agric. Food Sci. Finland 6:349-362.

Krebs, H. A., and P. Lund. 1966. Formation of glucose from hexoses, pentoses, polyols and related substances in kidney cortex. Biochem. J. 98:210-214.

Krebs, H. A., B. M. Notton, and R. Hems. 1966. Gluconeogenesis in mouse-liver slices. Biochem. J. 101:607-617.

LeBlanc, S. J., K. E. Leslie, and T. F. Duffield. 2005. Metabolic predictors of displaced abomasum in dairy cattle. J. Dairy Sci. 88:159-170.

Linke, P. L., J. M. DeFrain, A. R. Hippen, and P. W. Jordon. 2004. Ruminal and plasma responses in dairy cows to drenching or feeding glycerol. J. Dairy Sci. 87(Suppl. 1):343. (Abstr.)

Littell, R. C., P. R. Henry, and C. B. Ammerman. 1998. Staristical analysis of repeated measures data using SAS procedures. J. Anim. Sci. 76:1216-1231.

Littell, R. C., G. A. Milliken, W. W. Stroup, and R. D. Wolfinger. 1996. SAS ${ }^{\circledR}$ System for Mixed Models. SAS Inst. Inc., Cary, NC

Marsh, W. H., B. Fingerhut, and H. Miller. 1965. Automated and manual direct methods for the determination of blood urea. Clin. Chem. 11:624-627.

NRC. 2001. Nutrient Requirements of Dairy Cattle. 7th rev. ed. Natl. Acad. Sci., Washington, DC.

Ogborn, K. L. 2006. Effects of method of delivery of glycerol on performance and metabolism of dairy cows during the transition period. MS Thesis. Cornell Univ., Ithaca, NY.

Remond, B., E. Souday, and J. P. Jouany. 1993. In vitro and in vivo fermentation of glycerol by rumen microbes. Anim. Feed Sci. Technol. 41:121-132. 
SAS Institute. 1999. SAS/STAT User's Guide: Statistics, Version 8 Edition. SAS Inst. Inc., Cary, NC.

Schröder, A., and K.-H. Südekum. 1999. Glycerol as a by-product of biodiesel production in diets for ruminants. In New Horizons for an Old Crop. Proc. 10th Int. Rapeseed Congr., Canberra, Australia. Paper No. 241. N. Wratten and P. A. Salisbury, ed. The Regional Institute Ltd., Gosford, New South Wales, Australia.

Simon, A., H. Bergner, and M. Schwabe. 1996. Glycerol as a feed ingredient for broiler chickens. Arch. Tierernahr. 49:103-112.

Stokes, S. R., G. E. Kaiser, J. P. Goff, and C. L. Brawley. 2002. Effects of oral drenching of glycerol on blood parameters and milk production in dairy cattle at parturition. J. Dairy Sci. 85(Suppl. 1):190. (Abstr.)

Trinder, P. 1969. Determination of glucose in blood using glucose oxidase with an alternative oxygen acceptor. Ann. Clin. Biochem. 6:24-27.

Wildman, E. E., G. M. Jones, P. E. Wagner, R. L. Boman, H. F. Troutt, Jr., and T. N. Lesch. 1982. A dairy cow body condition scoring system and its relationship to selected production characteristics. J. Dairy Sci. 65:495-501.

Williamson, D. H., J. Mellanby, and H. A. Krebs. 1962. Enzymic determination of $\mathrm{D}(-)-\beta$-hydroxybutyric acid and acetoacetic acid in blood. Biochem. J. 82:90-96. 